\title{
Organizational Culture Change and Leadership Strategies: An Empirical Study on the Performance of PNTL (Empirical Study on the National Police of Timor-Leste)
}

\author{
Arquimino Ramos \\ Lecturer of Universidadeda Paz-UNPAZ-Timor-Leste andStudent at Doctoral Program at Wydia Mandala Surabaya Chatolic University
}

\begin{abstract}
This study is intended to measure the organizational performance of the National Police ofTimor-Leste by examining how the influence on Organizational Performance is caused by Strategic Leadership and Organizational Culture, with Organizational Citizenship Behavior as an intervening variable. This research uses the Quantitative Research method with PLS statistical analysis tools on a total population of 90 and 74 respondents as sample. Hypothesis H1: Influence of Strategic Leadership on Organizational Citizenship Behavior, H2: Influence of Organizational Culture on Organizational Citizenship Behavior, H3: Influence of Strategic Leadership on Organizational Performance, H4: Influence of Organizatinal Culture on Organizational Performance, H5: Influence of Organization Citizenship Behavior on Organizational Performance. The results showsthat Hypotheses 1-5 have a positive and significant influence to Organizational performance which means that the Strategic Leadership and Organizational Culturehave a positive and significant influence to Organizational Cytizenship Behaviour and the increased of Organizational Cytizenship Behaviour will be increase Organizational Performance.
\end{abstract}

Keywords: Strategic Leadership, OrganizationalCulture, Organizational Citizenship Behavior and Organizational Performance

\section{Introduction}

Buentello et al. (2006) in Exploring the Casual Relationship between Organizational Citizenship Behavior, Total Quality Management, and Performance found that there is no direct relationship between Organizational Citizenship Behavior and Organizational Performance. This study describes the mediating role of Total Quality Management on the relationship between Organizational Citizenship Behavior and Performance. These results provide several valuable managerial implications, for example managers employing Total Quality Management can improve their appraisal system to identify and reward employees who engage in Organizational Citizenship Behavior. However, the actions of employees in Organizational Citizenship Behavior are not directly reflected in the company's performance.

Yan \& Yan (2015) in Leadership, Organizational Citizenship Behavior, and Innovation in small business: an empirical study. Stating that the different dimensions used in Organizational Citizenship Behavior will have different effects on different aspects of organizational performance. Furthermore, it was found that there are several limitations that this research has: First, crossover data is used for analysis which makes it very difficult to draw causal relationships between the variables studied. It is suggested that further research should take a more comprehensive design so that a better understanding can be obtained. Second, using small businesses as a sample may limit the generalizability of the results to other types of organizations. Future research should examine other types of work environments. Third, the reliance on a single reporting source for each measure in this study may lead to two possible problems, firstly, the key informants used in this study. How efforts are made to minimize negative effects by obtaining respondents who hold the same or identical positions in small businesses, which helps to reduce the associated problem of lack of standardization. The second problem is that it may be perceived, inflation perception is carried out for a single reporting source for each measure. In future research statistical control techniques should be included in the questionnaire design to reduce the bias effect of desires.

From the description that has been stated that there are differences in research results, if it is related to the phenomenon of dissatisfaction with the performance of the PNTL in Timor-Leste, a research will be carried out with the title "The Influence of Strategic Leadership, Learning Organizations, and Organizational Culture on Organizational Performance with Organizational Citizenship Behavior as Variables Intervening at the Office of the National Police of Timor-Leste"

\subsection{Formulation of the problem}

Based on the background of the problem that has been described previously, the formulation of the problem in this study is:

1) Does Strategic Leadership affect Organizational Citizenship Behavior?

2) Does Organizational Culture affect Organizational Citizenship Behavior?

3) Does Strategic Leadership affect Organizational Performance?

4) Does Organizational Culture affect Organizational Performance?

5) Does Organizational Citizenship Behavior affect Organizational Performance? 


\subsection{Research purposes}

1) Proving and analyzing the influence of Strategic Leadership on Organizational Citizenship Behavior

2) Proving and analyzing the influence of Organizational Culture on Organizational Citizenship Behavior

3) Proving and analyzing the influence of Strategic Leadership on Organizational Performance

4) Proving and analyzing the influence of Organizational Culture on Organizational Performance

5) Proving and analyzing the effect of Organizational Citizenship Behavior on Organizational Performance.

\subsection{Benefits of research}

The results of this study are expected to provide benefits both theoretically and practically.

Based on the background of the problem, the formulation of the problem and the research objectives that have been stated above, this research is expected to provide benefits for the development of science, especially for the development of strategic management science, especially in making a more comprehensive contribution, and can provide empirical evidence on the influence of Strategic Leadership. , Organizational Learning and Organizational Culture on Organizational Performance with Organizational Citizenship Behavior as an intervening variable.

This research is a different kind of research because not many studies have been conducted with the aim of examining variables such as Strategic Leadership, Organizational Learning, Organizational Culture, Organizational Citizenship Behavior, and Organizational Performance, especially research in public organizations. In the context of the Timor-Leste National Police, this research is a new study because previously no research has been conducted with the above variables and new research methods.

The literature review in this article will describe previous studies related to this research topic such as Strategic Leadership, Organizational Culture, Organizational Citizenship Behavior, and Organizational Performance. Then the theories that become the basis for researchers in conducting research, as well as a description of the relationship between research variables.

\subsection{Previous Research}

Philips and Burbach (2010) in their research on Strategic Leadership in the Nonprofit Sector: Opportunities for Research suggest a study of how top-level leaders affect organizational performance, but it has not been widely extended to the non-profit sector. However, there are reasons to believe that strategic leadership contributes to the performance of nonprofit organizations in a way that is consistent with strategic leadership theory. From this opinion, it can be stated that strategic leadership does not only affect profit organizations but also affects non-profit organizations.
McLeod (2002) in Leading for A Purpose - Managerial Leadership Strategic Performance in Public Organizations said that the research findings show the potential impact of the operationalization of government and in particular the political context on strategic leadership efforts is significant. On that basis managing the future context is an important component of effective strategic leadership efforts in public organizations. This shows the importance of political context in the literature.

Pazireh, Akhlagh and Akbari (2014) conducted a study on Evaluation of the Role of Strategic Leadership in Organizational Performance suggesting that strategic leadership can have an effect on organizational performance through understanding work and environmental conditions and building interactions with employees. They align employee actions by determining strategic direction, facilitating the achievement of goals and performing work through developing core competencies, by developing human resources as a source of competitive advantage, maintaining an effective corporate culture in order to promote the spirit of competition, establishing strategic controls for creation and achieving performance. optimal organization.

Serfontein and Hough (2011) in Nature of the Relationship between Strategic Leadership, Operational Strategy and Organizational Performance suggest that the main contribution of this research is the assessment that strategic leadership has a direct and positive effect on operational excellence and performance in business organizations in South Africa. The managerial implication of the model built in this study is that leadership and executives in business organizations can apply high-performance strategic leadership practices to improve strategic orientation and best operationalization in their organizations. This research is also in accordance with the theory of strategic leadership in achieving organizational performance.

Khan, Ghouri and Awang (2013) in Leadership Styles and Organizational Citizenship Behavior in Small and Medium Scale Firms suggest that there have been important changes in the management of small and medium enterprises, especially after the entry of information technology aspects. Research in the field of business and management confirms that employees are activators of organizational resources and, therefore, are considered an important asset of the organization. Other available literature confirms the assumption that high employee citizenship behavior is the most influential factor and contributes a lot to the success of company performance. The contribution of fundamentally effective leadership to employee commitment and citizenship cannot be ignored.

\section{Institutional Theory}

In an organization, be it a business organization or a public organization, there will be many factors that affect the performance of the organization, both from the environment within the organization and from the environment outside the organization. Talking about organizational theory, there are many theories that can be used to explain the conditions in organizations. Because this study will examine and explain the relationship between variables that can affect the 
performance of National Police of Timor-Leste, a theory that can explain these relationships is also needed.Institutional theory is a theory that also focuses its attention on the existence and all things related to organizational activities, as stated by Gudono (2014:167) that "if we look at an organization is a social reality with the totality of problems that exist in it: legitimacy, culture, social norms, technology, crime, leadership, strategy, power sharing, etc. The main idea of "Institutional Theory" is that organizations are shaped by the institutional environment that surrounds them and thus the observation of organizations must be seen as a totality of symbols, language, or rituals that complement them.According to Arquimino Ramos $(2014 ; 194)$ Police is an organization under legal National Authority whis has power to prevent crimes, guarrante of the citizen's safety and security as well as their properties.

\section{Bureaucratic Theory}

The government in running the wheels of government requires the existence of state apparatus which is often called the bureaucracy. According to the language, the term bureaucracy comes from the French bureau which means office or desk, and the Greek kratein which means to regulate. Thus bureaucracy can be interpreted as regulating or ordering from the desk or office.As contained in many literatures, Weber in Nawawi (2009: 88) gives six (6) characteristics of bureaucracy as follows:1) The division of labor on the basis of specialization of functions and duties and each position is determined by the legal authority,2) There is a clear hierarchy of power, 3) Based on the formulated rules, it is recorded in a written document,4) The relationship that occurs in the organization is an impersonal relationship,5) Special training and competence are the main criteria for administrative positions so that skills and careers are the basis for promotion and selection of workers,6) Organizational activities demand full capacity of workers.

From the opinion above, it can be explained that the bureaucracy has a legal organizational structure and has a division of tasks according to their respective expertise to be able to provide maximum service to achieve organizational goals. For the government bureaucracy, the goal is to provide maximum service to the community.

\section{Strategic Leadership}

In an organization, it is very necessary to have a leader who can provide direction or instructions to members of the organization to carry out their duties and authorities in an effort to achieve organizational goals. Strategic Leadership is the implementation of leadership in general in the organization, so first it is necessary to understand the concept of leadership. Bass and Avolio (1993) suggest that Strategic Leadership is a process within the group. To be able to lead, the leader must do something in the group. Leadership is more than just authority. Although a formalized position of authority may greatly encourage the leadership process, simply occupying that position does not mark a person as a leader. Furthermore, Ireland and Hitt (1999) define Strategic Leadership as a person's ability to anticipate, create a vision, maintain flexibility, think strategically and collaborate with others to initiate changes that can create a good future for the organization.
Ireland et al. (1995) that Strategic Leadership has six components, namely:1) determine strategic direction (determining strategic direction),2) utilize and maintain important competencies (exploiting and maintaining core competencies),3) develop human resources (developing human capital),4) maintain an effective cooperation culture (sustaining an effective corporate culture),5) emphasizing ethical behavior (emphasizing ethical practices),6) establishing strategic control (establishing strategic control).

\section{Strategic Leadership inPublic Organization}

All organizations in an effort to achieve their goals require strategic leadership. Like business organizations, public organizations also need strategic leadership. The OECD, an institution for economic cooperation and development, in its report stated that in modern governance, leadership relationships are not only strategic but must also be able to usher in changes in public services. In full it is said that:

The leadership profile includes focusing on delivery of result, challenging assumptions, being open to learning from the out side, understanding the environment and it's impact, thingking and acting strategically, building new patterns and ways of working, and developing and communicating a personal vision of change (OECD: 2015).

\section{Organizational culture}

The term organizational culture emerged from the general concept of culture rooted in anthropological, historical, sociological and psychological perspectives. Kroeber \& Kluckhohn (1952) released a list containing 160 different definitions of culture as an indication of the diversity of concepts of the term culture. The importance of culture for a leader is emphasized by Schein (2010) with a statement "The bottom line for leaders is that if they do not become conscious of the cultures in which they are embedded, those cultures will manage them. Cultural understanding is desirable for all of us, but it is essential to leaders if they are to lead." It is said that the basic thing for leaders to know is that if they are not aware of the culture in which they are in, then that culture will govern them. Cultural understanding is expected by all of us, but it is very important for leaders if they are to lead.

\section{Organizational Citizenship Behavior (OCB)}

Organ (1988:31) defines Organizational Citizenship Behavior as individual behavior that is free, not directly related to the reward system and can improve the effective functioning of the organization. Borman and Motowidlo (1993) construct contextual behavior not only to support the core of the behavior itself but also to support the growing organizational, social and psychological environment so that the technical core functions. This definition does not express the terms voluntary or reward but rather behaviors that support the organizational environment, beyond its technical core. Organ, et al (2006) suggest that Organizational Citizenship Behavior (OCB) is a behavior that arises from the feeling of an individual as a member of the organization where the individual is located, and who has a sense of satisfaction if he can do something more than the organization expects. 
Podsakoff, et al (2009) suggested about the meaning of OCB through two approaches, such as among others: first, OCB is an extra role performance that is separated from in-role performance or performance that is produced according to job responsibilities or job descriptions. Second, namely that OCB is the effect or result of the impact of the belief in success that is owned by a person, which is the perception of individuals in the organization for the fulfillment of covenant relationships and psychological burdens. Chahal \& Mehta (2010) suggest that OCB can be interpreted to define staff behavior in an organization that is direct and leads to a role of one's expectations in the capacity of staff in the organization.

Fitria (2013) OCB involves several behaviors including helping others, volunteering for extra tasks, obeying workplace rules and procedures. These behaviors describe "employee added value" which is a form of prosocial behavior, namely positive, constructive and meaningful social behavior to help.

Research conducted by Van Scotter, et al (2000) suggests that OCB can be conceptualized as synonymous with the concept of contextual performance that supports the social and psychological environment in which one's task can take place well. Based on the above definitions, it can be concluded that Organizational Citizenship Behavior (OCB) is: (1) voluntary behavior. is not a forced action on matters that prioritize the interests of the organization; (2) individual behavior as a form of satisfaction based on performance, not formally ordered; (3) not directly and blatantly related to the formal reward system

\section{Reasons Underlying Organizational Citizenship Behavior (OCB)}

Organizational behavior departs from human behavior in a certain group caused by the influence of the organization on humans or vice versa by humans on the organization (Kadir, 2006) One approach to motives in organizational behavior comes from the study of McClelland (1976) and colleagues. According to McClelland, humans have three levels of motives, namely:

1) Achievement motive, encourages people to show a standard of excellence (excellence), seeking achievement from tasks, opportunities or competitions

2) Affiliation Motive, encourages people to create, maintain andimprove relationships with others

3) The power motive drives people to seek status and situationswhere they can control the work or actions of others

\section{Indicators of Organizational Citizenship Behavior}

With regard to the dimensions of Organizational Citizenship Behavior (OCB), Organ (1988) divides it into seven dimensions, as follows: first, the dimension of helpful behavior (helping behavior), namely the behavior of helping coworkers with feelings of being unburdened or voluntary, and avoiding the occurrence of problems that may arise. related to the work at hand.

Second, the dimension of compliance (obedience) to the organization, namely the behavior or actions carried out by employees or staff in accordance with the procedures and policies of the institution that exceeds the minimum expectations of the institution. Employees or staff who can internalize the regulations within the company consciously will be able to follow them even when they are being monitored.

Third, the dimension of sportsmanship, namely not protesting or complaining in the form of dissatisfaction regarding job or work discomfort, and being able to maintain a positive attitude when unable to fulfill personal desires, and having the will to allow someone to take action for the good of the group.

Fourth, the dimension of loyalty to the organization, namely the attitude to be more concerned with the interests of the company or institution than their own interests, and this is done because of the awareness of a sense of belonging to the company or institution for the advancement of the company or institution.

Fifth, the dimension of individual initiative, namely the awareness that arises from within an employee or staff to be enthusiastic and committed to working extra that exceeds the maximum performance than expected.

Sixth, the dimension of social quality, namely as an action or involvement of a staff or employee to be able to be responsible constructively in the process of togetherness in building relationships between employees or staff in a harmonious and good atmosphere for the progress of the company or institution.

Seventh, the dimension of self-development, namely the involvement of employees or staff in company or institutional activities to increase one's abilities and experience in order to carry out an activity or program that will benefit the company or institution.

Davenport \& Prusak (1998) divides Organizational Citizenship Behavior (OCB) into three sub-variables, namely: first, the existence of this sub-variable of compliance (obedience) explains the willingness of employees or staff to accept and comply with organizational rules and procedures with indicators a) Consistency carry out responsibilities as an employee b) Obey the rules

Second, sub-variable loyalty (loyalty). This sub-variable describes the willingness of employees or staff to place their personal interests as an advantage for the progress and continuity of the organization or institution with indicators: a) Helping work to be easy b) Increasing morale c) Rewarding colleagues' efforts d) Providing encouragement and rewards e) Forming a team to solve problems f) Friendliness in approach

Third, sub-variable participation (participation). This sub variable describes the willingness of employees or staff to actively develop all aspects of life in an organization. In this regard, the intended participation consists of: a) social participation, which is related to the involvement of employees or staff in organizational affairs and in organizational social activities; b) advocacy participation, which is related to the desire or willingness of employees or 
staff to develop the organization by providing support and innovative thinking; c) functional participation, which is related to employee or staff contributions that exceed the required work standards and this is done voluntarily.

Based on the five dimensions of measurement of Organizational Citizenship Behavior developed by Podsakoff and MacKenzie (2006), the indicators of this study were developed as follows:

1) Behavior of Helping Coworkers (Altruism) consists of:a. Ready to help colleagues in completing tasks voluntarily, b. Happy to help customers and guests without being asked by them, c. Happy to help others whose work is overloaded.

2) Behavior of Complying with Work Rules and Procedures (Conscientiousness) consists of; a. Employees often arrive at the office early so they are ready to work when the work schedule starts, $b$. Employees rarely spend time talking outside of work, c. Employees always come on time no matter the season or traffic problems and other obstacles

3) Willingness to tolerate without complaint (sportmanship); a. Employees rarely spend time complaining about trivial things, b. Employees always focus on improving work if something goes wrong instead of complaining about the mistakes I've made, c. Employees rarely exaggerate problems that occur in the work environment.

4) Involvement in Organizational Functions (Civic Virtue); a. Employees always keep abreast of developments in the work environment, b. Employees pay attention and participate in the success of important meetings in the work environment, c. Employees help organize increased cohesion between departments in the work environment.

\section{Organizational Performance}

Every organization, both business organizations and public organizations, will strive to achieve high performance. In general, organizational performance is the totality of the work achieved by an organization in accordance with the goals of the organization. Simons in Nawawi (2013:233234) states that performance measurement systems assist managers in monitoring the implementation of business strategies by comparing actual results with strategic goals and objectives. A company's goal of course is to provide the best service to consumers and can obtain financial benefits, while for public organizations the goal is how to provide maximum service to the community.

According to Robbin (2008) performance is the answer to the question "what are the results achieved by someone after doing something". Arquimino Ramos,(2015;165) performance is the quantity and quality of the achievement of tasks by organization's member. Performance is the quantity and quality of the achievement of tasks whether carried out by individuals, groups or organizations (Nawawi, 2006:62)

Lebans \& Euske (2006) provide several definitions of organizational performance as follows:
Performance is a set of financial and nonfinancial indicators which offer information on the degree of achievement of objectives and result.

1) Performance is dynamic, requiring judgement and interpretation.

2) Performance may be illustrated by using a casual model that describes how current actions may afffect future results.

3) Performance may be understood differently depending on the person involved in the assessment of the organizational performance.

4) To define the concept of performance is necessary to know its elements characteristic to each area of responsibility.

5) To report an organizations performance level, it is necessary to be able to quantify the results.

Irawan (2000: 17-18) suggests that performance is an efficient action, but in a more specific context, for example in relation to the organization and its employees, the general meaning still needs to be explained. In this particular context, the notion of performance or performance as the output of a worker, an output of a management process, or an organization as a whole, where the output must be shown concrete evidence and can be measured (compared to predetermined standards).

Based on two opinions about performance, it can be said that performance is the output of a process. If the output comes from and or as a result of the work of the organization, it is called organizational performance.

Performance is dynamic, rarely static, because there is no performance that is not influenced by factors outside of itself. Performance exists precisely because it is held by these other factors. Basically, the performance of an employee goes up and down, at certain times good, at certain times not good, and this will affect organizational performance. The most difficult task of organizational managers is to maintain performance in a stable and best possible condition. This is difficult to do because the manager of the organization is not someone who is outside the system, but is a component that is actually inside the organization he is fostering, so that organizational managers also need to be managed (Simamora, 2004: 102)

\section{Organizational Performance Indicators}

In measuring performance, it is necessary to have dimensions or indicators that can be used to assess the success of the organization. Nawawi (2013: 243) suggests several types of performance indicators that are often used in measuring organizational performance, namely input indicators (inputs), process indicators (process), output indicators (output), outcome indicators (outcomes), benefits indicators (benefit), and impact indicators.

Dwiyanto (2006) suggests that there are 5 indicators to measure the performance of the public bureaucracy, namely:

\section{1) Productivity}

The concept of productivity does not only measure the level of efficiency, but also the effectiveness of services. Productivity is generally understood as the ratio between input and output. Productivity is a level of 
organizational achievement in achieving goals, meaning the extent to which the goals that have been set can be achieved.

2) Quality of service:

The issue of service quality tends to become increasingly important in carrying out the performance of public organizations. Many negative views arise because of public dissatisfaction with the quality of services received by public organizations. Thus, community satisfaction with services can be used as an indicator of the performance of public organizations.

3) Responsiveness:

Responsiveness is the ability of the organization to recognize the needs of the community, develop service agendas and priorities and develop public service programs in accordance with the needs and aspirations of the community. As one of the performance indicators, responsiveness directly describes the ability of public organizations to carry out their mission and goals, especially to meet the needs of the community. Low responsiveness is indicated by the misalignment between services and community needs. This clearly shows the failure of the organization in realizing the mission and goals of public organizations.

4) Responsibility:

Explain/measure the suitability of the implementation of public organization activities carried out in accordance with correct administrative principles or in accordance with organizational policies.

5) Accountability:

How much public policies and activities are subject to political officials elected by the people or a measure that shows the level of conformity of service delivery with external norms or values that exist in society or those of stakeholders.Bernard and Russell (in Gomes, 2000) limit performance as a record of outcomes resulting from the function of a particular job or activity over a certain period of time. In this study, the performance in question is in the context of public organizations, namely the performance of the TimorLeste government ministries.

\section{Relationship between Variables}

\section{Strategic Leadership and Organizational Citizenship Behavior}

Khan, Ghouri and Awang (2013) examined Leadership Styles and Organizational Citizenship Behavior in Small and Medium Scale Firms. In this study, it was found that there were important changes in the management of small and medium enterprises, especially after the entry of information technology aspects. Research in the field of business and management confirms that employees are activators of organizational resources and, therefore, are considered an important asset of the organization. Other available literature confirms the assumption that high employee citizenship behavior is the most influential factor and contributes a lot to the success of company performance. The contribution of fundamentally effective leadership to employee commitment and citizenship cannot be ignored.

Other research on the influence of Leadership Style on Organizational Citizenship Behavior was conducted by Lamidi (2008) with the title "The Influence of Transformational Leadership on Organizational Citizenship Behavior: With Intervening Variables of Organizational Commitment". This study aims to examine the direct effect of transformational leadership on organizational commitment, the effect of transformational leadership on organizational citizenship behavior, and also examine the indirect effect of organizational commitment on organizational citizenship behavior. The results in this study indicate that: (1) there is a direct influence between transformational leadership and organizational commitment, (2) there is a direct influence between transformational leadership on the behavior of organizational citizens, (3) there is a direct influence between organizational commitment on organizational citizenship behavior and also (4) there is an indirect influence between transformational leadership and organizational citizenship behavior through organizational commitment.

\section{Organizational Culture and Organizational Citizenship Behavior}

Starbuck and Holloway (2008) suggest that there are at least four factors that can affect OCB, namely:

Cultural factors (culture), namely that employees or staff will be more likely to take actions that go beyond the work responsibilities they carry, if they: (a) are satisfied with their work, (b) can receive sportsmanship and attentive treatment from supervisors, (c) believe that they are treated fairly by the institution or organization.

Furthermore, organizational culture can be the cause of the quality of OCB development in an organization. In a positive organizational climate, employees or staff will feel more willing to do their work more than what is required in the job description, and will always support the organization's goals if they are treated by superiors with sportsmanship and with full awareness and believe that they are being treated. fairly by the organization

\section{Research Framework}

The variables that have been determined above have been based on theoretical and empirical studies. The theories used are contained in the literature and are based on previous studies. With prepositions based on theoretical and empirical studies as stated above, it will be known the indicators that will be the research targets and finally the determination of the hypotheses to be tested. Singarimbun and Effendi (1998) explain the hypothesis as a scientific tool which is a working instrument of theory. As a result of theoretical deduction or prepositions, the hypothesis is more specific and will ultimately be tested empirically. Based on the description above, the conceptual framework will be described in Figure as follows: 


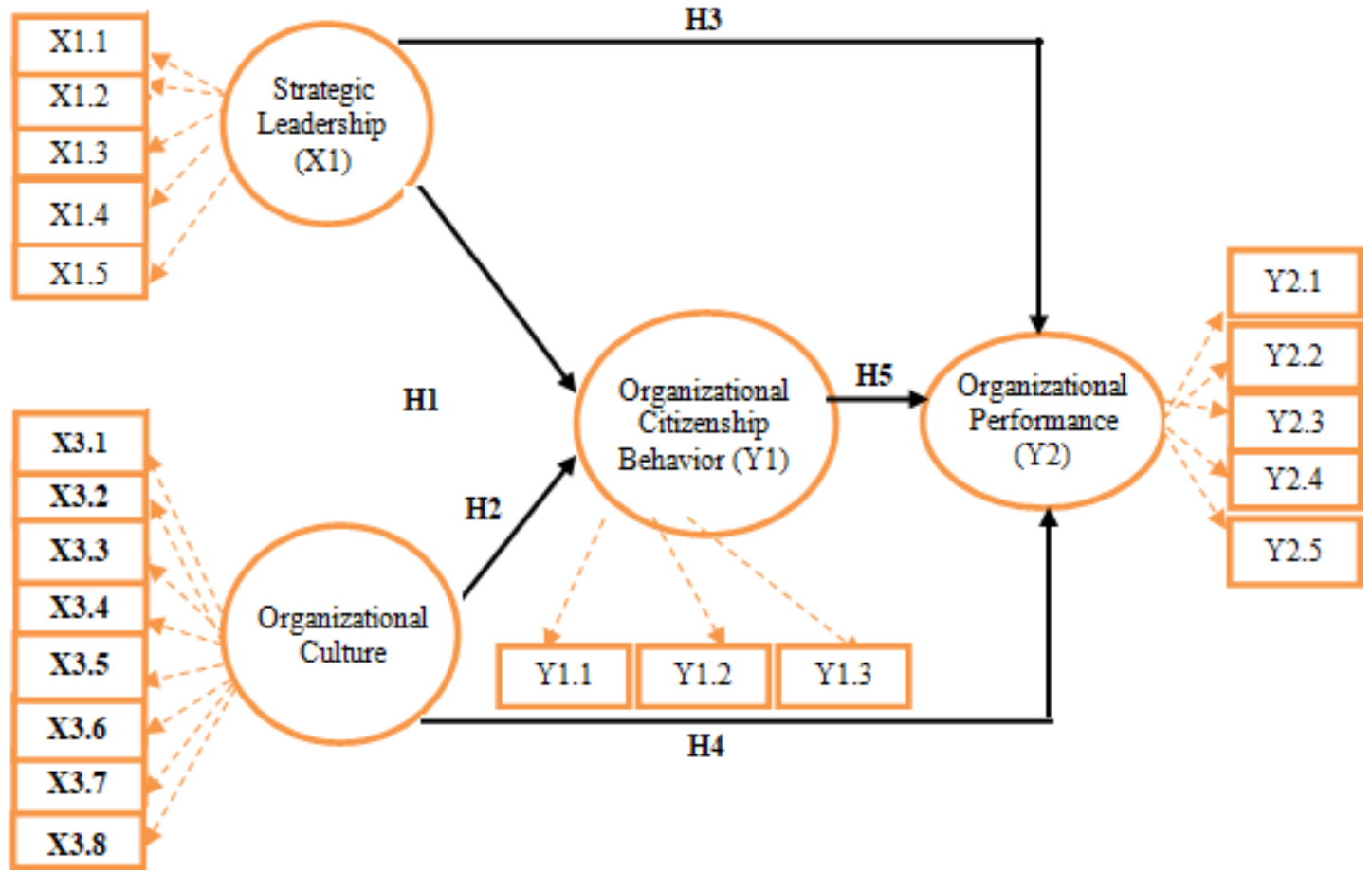

Explanation:

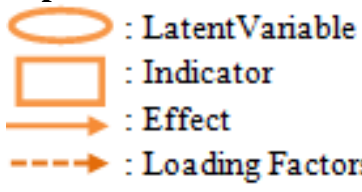

Figure: Research Framework

\section{Hypothesis}

The hypotheses proposed in this study were tested for truth by using theories and data obtained from the research sample. The test tool used to test the hypothesis in this study is a statistical test. With statistical tests, the hypothesis can be tested for truth so that it becomes a dissertation concept. Finally, a dissertation will be produced which is the final result of the research process.

H1: Influence of Strategic Leadership on Organizational Citizenship Behavior

$\mathrm{H} 2$ : Influence of Organizational Cultureon Organizational Citizenship Behavior

H3: Influence of Strategic Leadership on Organizational Performance

H4: Influence of Organizatinal Culture on Organizational Performance

H5: Influence of Organization Citizenship Behavior on Organizational Performance

\section{Population, Research Sample and Sampling Technique}

\section{Population and Research Sample}

The population is the group observed in the study consisting of objects that have certain qualities and characteristics determined by the researcher to be studied and drawn conclusions. Population is a combination of all elements in the form of events, things or people who have similar characteristics that become the center of attention of a researcher because it is seen as a research universe (Ferdinand, 2014:171). In certain studies, not all individuals in the population are respondents, but it is enough to take samples that can describe the nature of the population.
The population used in this study was 90 PNTL offices. While the research sample is part of the PNTL respondents. Clearly the number of ministries and respondents can be seen in table 1

Table 1: Population List

\begin{tabular}{|c|c|c|}
\hline No. & Office name & Number of respondents \\
\hline 1. & Station commander (Polsek) & 65 \\
\hline 2. & District Commander Resort (Polres) & 13 \\
\hline 3. & Unit and department Commander & 12 \\
\hline \multicolumn{2}{|c|}{ Total Population } & $\mathbf{9 0}$ \\
\hline
\end{tabular}

Source: Secondary data that has been processed

\subsubsection{Sample Size and Sampling Technique}

In this study, the sample size was determined using the Yamane approach in Ferdinand (2014), which is as follows: $n=\frac{N}{1+N d^{2}}$

Where:

$\mathrm{n}=$ number of samples

$\mathrm{N}=$ total population

$\mathrm{d}=$ specified precision or percentage of allowance for inaccuracy due to tolerable sampling error.

In this study the value of $d$ is $5 \%$, so the number of samples used by researchers are as follows:

$$
n=\frac{90}{1+90(0.05)^{2}}=73.469 \approx 74
$$

From the formula for determining the sample above, the sample size to be used is 74 PNTL offices. The sampling technique used in this study was Probability Sampling with a 
simple random sampling technique, while the determination of the sample size was taken proportionally at the Polsek and Resort Police offices with the following formula.

$$
n_{i}=\frac{N_{i}}{N} n
$$

The sample size is shown in table 2

Table 2: Total research sample

\begin{tabular}{|c|c|c|c|c|}
\hline No. & Position & Population & Calculation & Sample \\
\hline 1. & Station Commander & 65 & $\frac{65}{90} \times 74$ & 53 \\
\hline 2. & $\begin{array}{c}\text { Disctrict Commander } \\
\text { (Polres) }\end{array}$ & 13 & $\frac{13}{90} \times 74$ & 11 \\
\hline 3. & $\begin{array}{c}\text { Unit and Department } \\
\text { (Kepala Unit) }\end{array}$ & 12 & $\frac{12}{90} \times 74$ & 10 \\
\hline & Total & 90 & & 74 \\
\hline
\end{tabular}

Source: Secondary data that has been processed

\section{Variable Identification}

Research variables are basically anything determined by the researcher to be studied and then drawn conclusions. Variables can be symbols or numbers to which numbers or values are attached (Kerlinger, 2000: 49). Another definition of variable is the object of research, or what is the point of attention of a research Arikunto, (2002). In this study, there were three groups of variables, namely exogenous latent variables, intervening latent variables and endogenous latent variables. Exogenous latent variables consist of Strategic Leadership (X1), Organizational Learning (X2), Organizational Culture (X3), the intervening latent variable is only one variable, namely Organizational Citizenship Behavior (Y1), while the endogenous latent variable is Organizational Performance (Y2).

\section{Operational Definition and Measurement of Research Variables}

The variables in accordance with the conceptual framework in this study, are defined operationally as follows:

\section{X1 Strategic Leadership}

Strategic Leadership is a person's leadership ability which is reflected in his ability to think strategically in leading his members. So strategic leadership is the interaction of a leader with his subordinates. In these interactions, there are two orientations of leader behavior in interacting with subordinates, firstly relationship orientation, secondly on task, besides that, behavior that considers situational conditions.

Strategic leadership indicators refer to Burns, (2008):

1) Visionary / Visionary) (X1.1) namely the ability of a leader to be measured by a) Leaders have the ability to explain the ministry's vision to their employees, b) Leaders are able to invite employees to work well in order to realize organizational goals, c) Leaders have the ability to prepare employees for future challenges, d) Leaders have the ability to improve the abilities of employees.

2) Ability to manage change (X1.2) which will be measured by a) Leaders have the ability to read the changes that occur, b) Leaders have the ability to adopt new innovations in advancing the ministry, c) Leaders in respond to changes that occur by empowering employees, d) Leaders always try to improve ministry facilities to facilitate the implementation of the duties of their employees.

3) Ability to cohesion and sense of belonging (X1.3) which will be measured by a) Leaders are able to build cooperation among employees b) Leaders are able to generate a sense of togetherness among employees to feel as one unity, c) Leaders can foster a sense of belonging to employees towards their organization, d) Leaders are able to build employee confidence in their superiors.

4) Ability to think strategically / The ability to think strategically (X1.4) which will be measured by a) Leaders trying to find new ideas to improve employee performance, b) Leaders are able to improve the abilities of employees so that they can work according to with the goals of the organization, c) Leaders encourage employees to remain committed to the organization, d) Leaders are able to create harmonious relationships between employees.

5) Ability to generate trust (X1.5) which will be measured by a) Leaders pay attention to the problems faced by employees, b) Leaders are able to set good examples to employees, c) Leaders speak the truth and instill discipline to employees, d) Leaders act in accordance with applicable regulations.

\section{X2: Organizational Culture}

\section{Conceptual definition}

Organizational culture as a set of subconscious beliefs and assumptions that determine the values of the organization through which individual actions and collective actions of the organization will be formed (Schein, 1992)

\section{Operational definition}

Organizational culture is the perception of school leaders (principals and vice principals) about a shared set of core values, beliefs, understandings and norms as social glue, identity giver and organizational heritage through which individual and collective actions of an organization are shaped by a combination of three main categories namely innovative culture, bureaucratic culture and supportive culture with different intensities

(Operational Definition) Instrument Item Number; X2.1 Innovative culture is characterized by creative traits 13 , X2.2 Innovative culture characterized by results-oriented traits 14, X2.3 Innovative culture characterized by challenging $15, \mathrm{X} 2.4$ A supportive culture is characterized by collaboration $16, \mathrm{X} 2.5 \mathrm{~A}$ supportive culture is characterized by a relationship orientation 17, X2.6 A supportive culture is characterized by trust $18, \mathrm{X} 2.7$ Bureaucratic culture is characterized by hierarchical, procedural characteristics $19, \mathrm{X} 2.8$ Bureaucratic culture is marked by sanctions for violating regulations 20 .

\section{Organizational Citizenship Behavior (Y1),}

Organizational Citizenship Behavior (OCB) is a profound individual contribution that exceeds the demands of the role in the workplace and is rewarded by the achievement of task performance. This OCB involves several behaviors 
including helping others, volunteering for extra tasks, obeying the rules and procedures set in the workplace.

Organizational Citizenship Behavior (OCB) indicators refer to the measurements developed by Organ (1988): 1) Altruism / Helping Coworkers Behavior (Y1.1) will be measured by a) Every employee is always ready to replace his friend who is unable to attend, b) Every employee always provides assistance to a friend who is having difficulties, c) Every employee is willing to help his friend who is burdened overwork, d) Every employee is ready to help his friend without being asked.2) Conscientiousness / Behavior of Complying with Work Rules and Procedures (Y1.2) will be measured by a) employees always come to work on time, b) employees only take a break when it's time to rest, c) employees will not go home before work completed, d) in working every employee does not delay the work that is his obligation.3) Sportsmanship / Willingness to Tolerate without Complaints (Y1.3) will be measured by a) Every employee does not exaggerate problems that occur in the ministry, b) Every employee does not swear or complain at work, c) Every employee always maintains the integrity of the atmosphere work in the ministry, d) Every employee tries not to create problems in the ministry.4) Civic Virtue / Involvement in Organizational Functions (Y1.4) will be measured by a) Every employee always keeps the secrets in the ministry, b) Every employee always follows the developments faced by the ministry, c) Every employee always obeys the rules ministry, d) Every employee always makes judgments about what is best for the ministry.

\section{Y2 Organizational Performance}

Organizations need to measure performance as a material to evaluate the programs that have been carried out in order to determine the level of success of program implementation. In this study using performance indicators of public organizations referring to Dwiyanto (2006), namely:(1) Productivity (Y2.1) will be measured by a) The Ministry in carrying out its duties always experiences an increase in the number of people served, b) The Ministry in carrying out its duties always expands the types of services, c) The Ministry in carrying out its duties always shortens the time for completion of work, d) The Ministry in carrying out its duties always gives satisfaction to the community.(2) Service Quality (Y2.2) will be measured by a) the Ministry in carrying out its duties always tries not to make mistakes, b) the Ministry in carrying out its duties successfully as planned, c) the Ministry in carrying out its duties is always thorough, $d$ The Ministry in carrying out its duties is always on time.(3) Responsiveness (Y2.3) will be measured by a) the ministry in carrying out its duties always meets the needs of the community, b) the ministry in carrying out its duties always puts priority things first, c) the ministry in carrying out its duties always listens to the aspirations of the community, d) The Ministry in carrying out its duties always gives satisfaction to the community.(4) Responsibility / Responsibility (Y2.4) will be measured by a) The Ministry in carrying out its duties is always based on applicable regulations, b) The Ministry in carrying out its duties in accordance with the authority it has, c) The Ministry always pays attention to its employees to work in accordance with their duties, d) the ministry in carrying out its duties does not waste the state budget.(5) Accountability /
Accountability (Y2.5) will be measured by a) The Ministry in carrying out its duties always makes a policy of fast service, b) The Ministry in carrying out its duties always puts the public interest first, c) The Ministry in providing services does not discriminate against the public, d) The Ministry is always accountable for its duties to the community.

\section{Measurement Scale}

The measurement scale used is a Likert scale, namely, an interval scale of 1 to 5 .

\section{Types, Sources and Data Collection}

\section{Data Types and Sources}

In this study, a number of data are needed, namely primary data and secondary data. To obtain primary data, it will be done by distributing questionnaires to PNTL heads. Secondary data here is data and supporting information obtained and has been processed by other parties (Nazir, 2000: 21). The types or kinds of secondary data that have been collected are the vision and mission as well as organizational performance.

\section{Data collection}

To obtain all data and information from respondents, a questionnaire will be distributed containing a number of questions to be answered by each respondent. In this study a questionnaire will be distributed to the heads of each PNTL office. Thus all the data and information needed in this study will be complete to be used as material in conducting the analysis in accordance with the existing problems. This criterion is also an illustration of the measurement of the accuracy of the concept being assessed. The information taken in this study has high validity and reliability.

\section{Processing and data analysis}

The instrument used in this study was a questionnaire or questionnaire. In the questionnaire there are a number of questions that must be answered by the respondent in accordance with the things that are known so that the data and information needed will be obtained.

In this study, hypothesis testing uses quantitative methods with statistical tests with Partial Least Square (PLS) data analysis models. The data needed for hypothesis testing are collected in such a way, and compiled based on theoretical constructs (based on previous research). Question items are in the form of interval and ordinal with a closed and open questionnaire model. In answering items related to the degree or tendency of several variables in this study as stated previously, questions in the form of a Likert scale were used to allow respondents to answer various levels of questions, namely (strongly agree, agree, neutral, disagree, strongly disagree). With the provision of a scale will determine the determination of the score scale on each question from the respondent. The probability of getting the largest score is 5 and the smallest score is 1 or vice versa.

\section{Data analysis method}

To achieve the research objectives and the proposed hypothesis, all data and information collected will then be processed according to the needs of the analysis. For the 
purposes of discussion, the data is processed and presented based on the principles of descriptive statistics. Then for the purposes of analysis and hypothesis testing, an inferential statistical approach is used. The analysis used to answer the hypothesis in this study uses the Partial Least Square (PLS) structural equation model.

Partial Least Square (PLS) was first developed by Herman Wold (1982) and is often called soft modeling. By using PLS, it is possible to model structural equations with relatively small sample sizes and do not require multivariate normal assumptions. There are several methods developed related to PLS, namely PLS Regression (PLS-R) and PLS Path Modeling (PLS-PM). PLS Path Modeling was developed as an alternative to structural equation modeling (SEM) which has a weak theoretical basis.

There are several things that distinguish PLS analysis from other SEM analysis models:

1) The data does not have to be normally distributed multivariate.

2) Small samples can be used. Minimum sample $>30$ can be used.

3) PLS besides being able to be used to confirm theory, it can also be used to explain whether or not there is a relationship between latent variables.

4) PLS can analyze as well as constructs formed with reflective and formative indicators.

5) PLS is able to estimate large and complex models with hundreds of latent variables and thousands of indicators (Falk and Miller, 1992).

PLS is a powerful analytical method because it can be applied to all data scales, does not require many assumptions and the sample size does not have to be large. Besides being able to be used as a confirmation of theory, PLS can also be used to build relationships that do not have a theoretical basis or to test propositions. PLS can also be used for structural modeling with reflective or formative indicators.

Ghozali (2006) said that Partial Least Square (PLS) is an analytical method that is not based on many assumptions. The purpose of PLS is to predict a model and confirm existing theories, but it can also be used to explain whether or not there is a relationship with latent variables. Furthermore, Ghozali (2006) added that the specification model in SEM-PLS uses a path analysis model. This means that all latent variables in PLS consist of three sets of relationships, namely: First, the inner model. Second, the waight relation, refers to the case value of the latent variable that can be estimated. Third, the outer model, refers to the specification of the relationship between variables and indicators (manifest variables or measurement models).

\section{A. Inner Model (Structural Model).}

Tests on the structural model were conducted to examine the relationship between latent variables based on substantive theory. The equation model is as follows:

$$
\eta=\beta 0+\beta \eta+\tau \xi+\zeta
$$

$\eta$ describes the endogenous vector (response) of the latent variable. is the vector of the exogenous latent variable, and is the vector of the residual variable. Because the PLS model is designed for a recursive model, the relationship between latent variables, each response latent variable $\eta$ or often referred to as the causal Cain system of latent variables can be described as follows:

$$
\eta_{j}=\sum_{i} \beta_{j i} \eta_{i}+\sum_{i} \partial_{j i} \xi_{j}+\xi_{j}
$$

$\beta_{j i}$ and $\partial_{j i}$ is coefisien

pathways linking endogenous predictors and exogenous latent variables $\xi$ and $\eta$ along the index range $\mathrm{i}$ and $\mathrm{b}$, and $\zeta j$ is inner variabel.

Estimate for Path Coefficients, is a value There are several tests for the structural model, namely:

1) R Square on the endogenous construct. The value of $R$ Square is the coefficient of determination on the endogenous construct. According to Chin (1998), the value of $\mathrm{R}$ square is 0.67 (strong), 0.33 (moderate) and 0.19 (weak).

2) Path coefficient or the magnitude of the relationship/influence of latent constructs. Done with Bootrapping procedure.

3) Effect Size (f square). Done to know the goodness of the model.

4) Prediction relevance ( $Q$ square) otherwise known as Stone-Geisser's. This test was conducted to determine the predictive capability with the blindfolding procedure. If the value obtained is 0.02 (small), 0.15 (medium) and 0.35 (large). It can only be done for endogenous constructs with reflective indicators, and can be described as follows:

$$
Q^{2}=1-\left(1-R_{1}^{2}\right)\left(1-R_{2}^{2}\right) \ldots . .\left(1-R_{5}^{2}\right)
$$

\section{B. Outer model (Model Measurement)}

In the outer model, there are two types of indicators, namely reflective indicators and formative indicators. This model specifies the relationship between latent variables and their indicators. or it can be said that the outer model defines how each indicator relates to its latent variables.

1. Reflective indicator. This indicator has the following characteristics: the direction of the causal relationship from the latent variable to the indicator, the indicators are expected to be correlated (the instrument must have consistency reliability), eliminate one indicator, will not change the meaning and meaning of the variable being measured, and measurement error (error) on indicator level.

Reflective indicators can be described in the following equation:

$$
\begin{aligned}
& x=\wedge_{x} \xi+\varepsilon_{x} \\
& y=\wedge_{y} \eta+\varepsilon_{y}
\end{aligned}
$$

$\mathrm{x}$ and $\mathrm{y}$ adalah is indicator for latent exogenous variable $\xi$ and $\eta$ is endogenous, sedangkan $\Lambda \mathrm{x}$ and $\Lambda \mathrm{y}$ is a loading matrix that describes a simple regression coefficient that relates the latent variable to the indicator.

2. Formative indicators. The characteristics of the formative indicator model are: the direction of the causal relationship from the indicator to the latent variable, the indicators are 
assumed to be uncorrelated (no internal consistency reliability test is needed), eliminating one indicator results in changing the meaning of the latent variable, and measurement error is at the level of the latent variable. . Latent variables with formative indicators can be composite variables. For example, the socio-economic status variable is measured by mutually exclusive indicators (education, occupation, and place of residence). Service quality variable is formed by 5 dimensions, namely tangible, reliability, responsive, empathy and assurance. This model specifies the relationship between latent variables and their indicators. or it can be said that the outer model defines how each indicator relates to its latent variables.

The tests carried out for reflective indicators are:

1) Convergent Validity. The value of convergent validity is the value of the loading factor on the latent variable with its indicators. Expected value $>0.7$.

2) Discriminant Validity. This value is a cross loading factor value that is useful for determining whether the construct has an adequate discriminant, namely by comparing the loading value on the intended construct which must be greater than the loading value with other constructs.

3) Composite Reliability. Data that has composite reliability $>0.8$ has high reliability.

4) Average Variance Extracted (AVE). Expected AVE value $>0.5$.

5) Cronbach Alpha. The reliability test was strengthened by Cronbach Alpha. The expected value was $>0.6$ for all constructs.

Test For formative indicators, different tests are carried out. The tests for formative indicators are:

1) Significance of weights. The value of the formative indicator weight with its construct must be significant.

2) Multicollinearity. Multicollinearity test was conducted to determine the relationship between indicators.

\section{Results and Discussion}

In addition to using the outer loading value, validity testing on SMART PLS can also be done by looking at the AVE value which is presented in the following table:

Table 3: AVE. value

\begin{tabular}{|c|c|}
\hline & $\begin{array}{c}\text { Average Variance } \\
\text { Extracted (AVE) }\end{array}$ \\
\hline Organizational Citizenship Behavior & 0.650 \\
\hline Organizational Culture & 0.694 \\
\hline Organizational Performance & 0.639 \\
\hline Strategic Leadership & 0.616 \\
\hline
\end{tabular}

From the table above, it can be seen that the AVE value generated by all reflective constructs is above 0.5 so that it meets the validity requirements.

The next examination of convergent validity is construct reliability by looking at the output of composite reliability or Cronbach's alpha. The criteria are said to be quite reliable if the composite reliability value or Cronbach's alpha is more than or equal to 0.3 but better if it is above 0.7 . Here is cronbach's alpha output.
Table 4: Reliability Test

\begin{tabular}{|c|c|c|}
\hline & $\begin{array}{c}\text { Cronbach's } \\
\text { Alpha }\end{array}$ & $\begin{array}{c}\text { Composite } \\
\text { Reliability }\end{array}$ \\
\hline Organizational Citizenship Behavior & 0.964 & 0.967 \\
\hline Organizational Culture & 0.937 & 0.948 \\
\hline Organizational Performance & 0.970 & 0.973 \\
\hline Strategic Leadership & 0.967 & 0.970 \\
\hline
\end{tabular}

From the output above, it shows that the value of Cronbach's alpha produced by all constructs is very good, which is above 0.7 so it can be concluded that all indicators of reflexive constructs are reliable or meet the reliability test. In addition, from the composite reliability value, all reflexive constructs are very good, above 0.7 , so it can be concluded that all reflexive construct indicators are reliable or meet the reliability test.

\section{Inner Model Evaluation}

In the evaluation of the inner model (structural model) the results of the R-Square and hypothesis testing will be explained.

\section{Structural Equation}

Structural equations are used to test the relationship between variables that were previously hypothesized, to examine this, structural equations are proposed in this research model that can be used as a structural model fit test, namely:

$\mathrm{OCB}=0.427 \mathrm{SL}+0.247 \mathrm{OC}, \mathrm{R} 12=32.4 \%$

$\mathrm{OP}=0.317 \mathrm{SL}+0.359 \mathrm{OC}+0.384 \mathrm{OCB}, \mathrm{R} 22=70.3 \%$

Source: Appendix 7

Information:

OCB = Organizational Citizenship Behavior

$\mathrm{SL}=$ Strategic Leadership

$\mathrm{OC}=$ Organizational Culture

$\mathrm{OP}=$ Organizational Performance

\section{Based on these structural equations, it can be explained} as follows:

1) Strategic leadership has a positive effect on organizational citizenship behavior with a coefficient of 0.427, meaning that if strategic leadership increases, organizational citizenship behavior will also increase by 0.427 .

2) Organizational culture has a positive effect on organizational citizenship behavior with a coefficient of 0.247 , meaning that if organizational culture increases, organizational citizenship behavior will also increase by 0.247 .

3) Strategic leadership has a positive effect on organizational performance with a coefficient of 0.317 , meaning that if strategic leadership increases, organizational performance will also increase by 0.317 .

4) Organizational culture has a positive effect on organizational performance with a coefficient of 0.359 , meaning that if organizational culture increases, organizational performance will also increase by 0.359 .

5) Organizational citizenship behavior has a positive effect on organizational performance with a coefficient of 0.384 , meaning that if organizational citizenship behavior increases, organizational performance will also increase by 0.384 . 
Berdasarkan persaman-persamaan struktural tersebut, dapat dijelaskan yaitu sebagai berikut:

1) Strategic leadership berpengaruh positif terhadap organizational citizenship behavior dengan koefisien sebesar 0,427 artinya, apabila strategic leadership meningkat, maka organizational citizenship behavior juga akan meningkat sebesar 0,427.

2) Organizational culture berpengaruh positif terhadap organizational citizenship behavior dengan koefisien sebesar 0,247 artinya, apabila organizational culture meningkat, maka organizational citizenship behavior juga akan meningkat sebesar 0,247.

3) Strategic leadership berpengaruh positif terhadap organizational performance dengan koefisien sebesar 0,317 artinya, apabila strategic leadership meningkat, maka organizational performance juga akan meningkat sebesar 0,317 .

4) Organizational culture berpengaruh positif terhadap organizational performance dengan koefisien sebesar 0,359 artinya, apabila organizational culture meningkat, maka organizational performance juga akan meningkat sebesar 0,359 .

5) Organizational citizenship behavior berpengaruh positif terhadap organizational performance dengan koefisien sebesar 0,384 artinya, apabila organizational citizenship behavior meningkat, maka organizational performance juga akan meningkat sebesar 0,384.

\section{R-Square Nilai Value}

Based on the above equation, it is known that the R-Square value for organizational citizenship behavior is 0.324 , which means that the percentage of organizational citizenship behavior that can be explained by strategic leadership and organizational culture is $32.4 \%$. The remaining $67.6 \%$ is explained by other factors outside the model studied. The RSquare value for organizational performance is 0.703 , which means that the percentage of organizational performance that can be explained by strategic leadership, organizational culture, and organizational citizenship behavior is $70.3 \%$. The remaining $29.7 \%$ is explained by other factors outside the model studied.

\section{Hypothesis testing}

The next evaluation is hypothesis testing. The research hypothesis can be accepted if the t-statistic value is $>1.96$. The following is the coefficient of influence (original sample estimate) and the value of t-statistics on the inner model:

Table 5: Coefficient of Influence and T-Statistic

\begin{tabular}{|c|c|c|c|c|c|}
\hline Hypothesis & Effect & Coefficient & t-statistic & P-value & Decision \\
\hline H1 & Strategic Leadership ->Organizational Citizenship Behavior & 0.427 & 3.554 & 0.000 & Positive and significant \\
\hline H2 & Organizational Culture ->Organizational Citizenship Behavior & 0.247 & 2.413 & 0.016 & Positive and significant \\
\hline H3 & Strategic Leadership ->Organizational Performance & 0.317 & 3.700 & 0.000 & Positive and significant \\
\hline H4 & Organizational Culture ->Organizational Performance & 0.359 & 4.166 & 0.000 & Positive and significant \\
\hline H5 & Organizational Citizenship Behavior ->Organizational Performance & 0.384 & 3.623 & 0.000 & Positive and Significant \\
\hline
\end{tabular}

From Table 5, the results of hypothesis testing can be explained as follows:

\section{Hypothesis 1}

The coefficient of the influence of strategic leadership on organizational citizenship behavior has a coefficient value of 0.427 with a t-statistic of 3.554 which is greater than the $t$ table of 1.96. In the table it can also be seen that the p-value is 0.000 which is smaller than 0.05 . These results indicate that there is a positive and significant influence between strategic leadership on organizational citizenship behavior. So it can be said that if strategic leadership has increased, then organizational citizenship behavior will also increase significantly. Based on these results the first hypothesis in this study was accepted.

\section{Hypothesis 2}

The coefficient of the influence of organizational culture on organizational citizenship behavior has a coefficient value of 0.247 with a t-statistic of 2.413 which is greater than the ttable of 1.96. In the table it can also be seen that the p-value is 0.016 which is smaller than 0.05 . These results indicate that there is a positive and significant influence between organizational culture on organizational citizenship behavior. So it can be said that if organizational culture has increased, then organizational citizenship behavior will also increase significantly. Based on these results the second hypothesis in this study was accepted.

\section{Hypothesis 3}

The coefficient of the influence of strategic leadership on organizational performance has a coefficient value of 0.317 with a t-statistic of 3.700 which is greater than the t-table of 1.96. In the table it can also be seen that the p-value is 0.000 which is smaller than 0.05 . These results indicate that there is a positive and significant influence between strategic leadership on organizational performance. So it can be said that if strategic leadership has increased, then organizational performance will also increase significantly. Based on these results the third hypothesis in this study was accepted.

\section{Hypothesis 4}

The coefficient of the influence of organizational culture on organizational citizenship behavior has a coefficient value of 0.359 with a t-statistic of 4.166 which is greater than the ttable of 1.96. In the table it can also be seen that the p-value is 0.000 which is smaller than 0.05 . These results indicate that there is a positive and significant influence between organizational culture on organizational performance. So it can be said that if the organizational culture has increased, the organizational performance will also increase significantly. Based on these results the fourth hypothesis in this study was accepted.

\section{Hypothesis 5}

The coefficient of the effect of organizational citizenship behavior on organizational citizenship behavior has a coefficient value of 0.384 with a t-statistic of 3.623 which is greater than the t-table of 1.96. In the table it can also be 
seen that the p-value is 0.000 which is smaller than 0.05 . These results indicate that there is a positive and significant effect between organizational citizenship behavior on organizational performance. So it can be said that if organizational citizenship behavior has increased, then organizational performance will also increase significantly. Based on these results the fifth hypothesis in this study was accepted.

The results shows that Hypotheses 1-5 have a positive and significant influence to Organizational performance which means that the Strategic Leadership and Organizational Culture have a positive and significant influence to Organizational Cytizenship Behaviour and the increased of Organizational Cytizenship Behaviour will be increase Organizational Performance.

\section{References}

[1] Ahmed, N., A. Rasheed., K. Jehanzeb. (2012). “An Exploration of Predictors of Organizational Citizenship Behaviour and its Significant Link to Employee Engagement", International Journal of Business, Humanities and Technology, Vol. 2 No. 4, pp.99-106.

[2] Aldag, Ray., Reschke, Wayne., (1997), Employee Value Added, New-York, Center for Organizational Effectiveness Inc.

[3] Allison, J. Barbara., Voss, S. Richard., Houston, C. Richard., (2001), An Empirical Investigation of The Impact of SDB on The Relationship Between $O C B$ and IndividualPerformance.

[4] Angle, H. L. and J. L. Perry, (1981), An Empirical Assessment of Organizational Commitment and Organizational Effectiveness, Administrative Science Quarterly 27: 1-14.

[5] Appelbaum, E, Bailey, T, Berg, P and Kalleberg, A L (2000) Manufacturing Advantage: Why high performance work systems pay off, ILR Press, Ithaca, NY.

[6] Arikunto, Suharsimi. (2002). Research Procedure/Prosedur penelitian, Suatu Pendekatan Praktek. Edisi Revisi V. Rineka Cipta. Jakarta.

[7] Armstrong Michael, (1990), A Hand Book Personnel Management Practice, Fourth Edition, Kogan Page Limited, London.

[8] Bacal, (2001), Performance Management, P.T. Gramedia Pustaka Utama,Jakarta.

[9] Bagyo, Y. (2013). "Organizational citizenship Behavior as Attitude Integrity in Measurement of Individual Performance Appraisal", Journal of Business and Management, Vol. 12, Issue 2 (Jul. Aug. 2013), pp.63-67.

[10] Baldwin, T.T., C. Danielson, and W. Wiggenhorn, (1997), The Evolution of Learning Strategies in Organizations: From Employee Development to Business Redefinition, Academy of Management Executive, November, pp.47-58.

[11] Barksdale, K., dan J.M Werner. (2001). "Managerial ratings of in-role behaviors, organizational citizenship behaviors, and overall performance: testing different models of their relationship", Journal of Business Research, Vol. 51, pp. 145-155.
[12] Bass, B., \& Avolio. (1993-Spring). Transformational Leadership and Organizational Culture. Public Administration Quartely, 17:1, 112-122.

[13] Beer, M, Spector, B, Lawrence, P, Quinn Mills, D and Walton, R, (1984), Managing Human Assets, The Free Press, New York.

[14] Benson, G S, Young, S M and Lawler, E E, (2006), High Involvement Work Practices and Analysts' Forecasts of Corporate Performance, Human Resource Management, 45 (4), pp 519-27

[15] Bernardin, H \& Russel, E. (1993). Human Resource Management: An Experimental Approach, Singapore, McGraw-Hill Inc.

[16] Bolino, M. C., (1999), Citizenship and impression management: Good soldiers or good actors?, Academy of Management Review, 24: 82-98.

[17] Buentello, O., J. Jung., J. Sun. (2008). “Exploring The Casual Relationships Between Organizational Citizenship Behavior, Total Quality Management, And Performance". University of Texas-Pan American.

[18] Burns, P. (2008). Corporate Entrepreneurship Building the Enterpreneurial Organization, Second edition, NY Plagrave Mcmilan.

[19] Cooper, D.R. \& Schindler, P.S. (2003). Business Research Methods. Boston, Irwin McGraw-Hill International.

[20] Chughtai, A.A. (2008). Impact of Job Involvement on In-Role Job Performance and Organizational Citizenship Behaviour. Institute of Behavioral and Applied Management.

[21] Cleveland, J. and P. Plastrik, (1995). Learning, Learning Organization and TQM. In A.M. Hoffman and D.J. Julius (Eds), Total Quality Management: Implications for Higher Education, Maryville, MO: Prescott, pp. 233-243.

[22] Darsana, M. (2013). "The Influence Of Personality And Organizational Culture On Employee Performance Through Organizational Citizenship Behavior", The International Journal Of Management,Vol.2, Issue 4, pp.35-42.

[23] Dharma, Surya. (2011). Performance Management; Philosophy, Theory and Its Aplication, Pustaka Pelajar, Yogyakarta.

[24] Dwiyanto, Agus. (2006). Cost and Bebefit Analises/Analisis Biaya Manfaat. Pusat Penelitian Kependudukan, Universitas Gadjah Mada, Yogyakarta.

[25] Dyer, L., Holder, G, (1988), a Strategic Perspective of Human Resource Management, in Dyer, L., Holder, G. (Eds),Human Resource Management: Evolving Roles and Responsibilities, The Bureau of National Affairs, Washington, DC, pp.1-46.

[26] Emory, C., \& Cooper, D. R. (1999). Business Research Method, 5th Edition. Chicago: Richard D. Irwin Inc. 